\title{
JUIZADOS ESPECIAIS: ENTRE A LEGALIDADE E A LEGITIMIDADE - ANÁLISE PROSPECTIVA DOS JUIZADOS ESPECIAIS DA COMARCA DE NITERÓI, 1997-2005
}

\author{
Marcelo Pereira de Mello e Delton R. Soares Meirelles
}

SPECIAL COURTS: BETWEEN LEGALITY AND LEGITIMACY - PERSPECTIVE ANALYSIS OF NITERÓI JUDICIAL DISTRICT COURTS, 1997 - 2005

\section{RESUMO}

A CHAMADA JUDICIALIZACÃO DAS QUESTÕES SOCIAIS E POLÍTICAS TEM PROVOCADO DEBATES ACERCA DO ACESSO À JUSTIÇA E DA LEGITIMIDADE DAS DECISÕES JUDICIAIS. NESSE CONTEXTO, RESULTANTE DOS DEBATES QUE PRECEDERAM A CONSTITUIC̄ÃO DE 1988, OS JUIZAdos EsPECIAIS FORAM PENSADOS COMO UM MODELO INSTITUCIONAL ALTERNATIVO AO JUDICIÁRIO ESTATAL, FORMALISTA, BUROCRÁTICO E CENTRALIZADO. SEGUNDO O ESPÍRITO DAS DISCUSSÕES ENTÃO PREVALENTES ENTRE OS CONSTITUINTES E A PREVISÃO CONSTITUCIONAL FIXADA NA ÉPOCA, OS JUIZADOS ESPECIAIS DEVERIAM SE DEDICAR À APRECIAÇÃO E AO JULGAMENTO DE CONFLITOS E CRIMES COM PEQUENO POTENCIAL OFENSIVO, ABRINDO A SUA COMPOSIC̣ÃO PARA A PARTICIPACỸ̃O DE JUÍZES LEIGOS. NESTA PESQUISA, NÓS ANALISAREMOS OS LITÍGIOS JULGADOS NOS Juizados EspeciaIs de Niteról, ESTAdo do RIO dE JANEIRO, COM OS SEGUINTES OBJETIVOS: Al CONTEXTUALIZAR O PROBLEMA DA LEGITIMIDADE DAS DECISÕES DOS JUIZADOS ESPECIAIS, ENFOCANDO A OPOSICÃO ENTRE O MODELO DA LEGITIMIDADE JUDICIAL ESTATAL, BUROCRÁTICA E LEGALISTA E O MODELO DEMOCRÁTICO DE PARTICIPACÃO CIDADÃ; B] ESTABELECER COMPARAÇÕES ENTRE A CULTURA JURÍDICA BRASILEIRA E OS PADRÕES CONTEMPORÂNEOS DE LEGITIMIDADE DO JUDICIÁRIO; C) VERIFICAR A EFETIVIDADE DAS DECISÕES DOS JuIZADOS ESPECIAIS.

PALAVRAS-CHAVE

JUIZADOS ESPECIAIS; JUSTIÇA; LEGITIMIDADE.

\section{ABSTRACT}

THE SO-CALLED "JUdiCIALIZAÇÃO" (JUDICIALIZATION) OF POLITICAL AND SOCIAL ISSUES HAS PROVOKED SOME DEBATES ON THE ACCESS TO JUSTICE AND LEGITIMACY OF JUDICIAL DECISIONS. IN THIS CONTEXT, DURING THE DEBATES THAT PRECEDED THE BRAZILIAN CONSTITUTION OF 1988, THE BRAZILIAN SMALL CLAIMS COURTS WERE THOUGHT AS AN INSTITUTIONAL ALTERNATIVE TO THE CENTRAL, BUROCRATIC AND FORMALIST STATE JUDICIARY. ACCORDING TO THE SPIRIT OF THE DEBATES PREVAILING AMONG THE CONSTITUENTS AND THE CONSTITUTIONAL PRESCRIPTION, THE SMALL CLAIMS COURTS SHOULD DEDICATED TO JUDGE AND RESOLVE SMALL CLAIMS AND CRIMES, OPENING ITS COMPOSITION TO THE PARTICIPATION OF LAY JUDGES. IN THIS RESEARCH, WE'LL anALYSE THE LITIGATIONS AT THE SMALL CLAIMS COURTS OF NITERÓl, STATE OF RIO DE JANEIRO, WITH THE FOLLOWING GOALS: Al CONTEXTUALIZE THE ISSUE OF LEGITIMACY OF THE DECISIONS of THE SMALL CLAIMS COURTS, FoCUSing ON THE OPPOSITION BETWEEN THE LEGITIMACY OF THE LEGALISM, BUROCRATICISM OF THE STATE JUSTICE AND THE DEMOCRATIC MODEL OF CITIZENSHIP AND JUSTICE; BI ESTABLISH COMPARATIVE ANALYSES BETWEEN THE BRAZILIAN LEGAL CULTURE AND THE CONTEMPORARY PATTERNS OF THE JUDICIARY LEGITIMACY; C) VERIFY THE EFFECTIVENESS OF THE SMALL CLAIMS COURTS DECISIONS.

\section{KEYWORDS}

SMALL CLAIMS COURTS; JUSTICE; LEGITIMACY. 


\section{INTRODUÇÃO}

Este trabalho procura investigar a atuação dos Juizados Especiais da comarca de Niterói, no estado do Rio de Janeiro, particularmente nas causas envolvendo conflito de vizinhança cujo valor tenha respeitado o limite legal de quarenta salários mínimos. Também procura constatar até que ponto a estrutura e o funcionamento desses juizados têm atendido ou não aos ideais de uma justiça informal e célere, desatrelada do formalismo legalista e burocrático da chamada justiça comum, assim como se a legitimidade das suas decisões tem sido lastreada ou não pelos ideais comunitários de justiça, conforme o espírito prevalente nas discussões parlamentares que ensejaram a Constituição de 1988.

Para esta avaliação, foram utilizados dados quantitativos com o total dos feitos e dos tipos de demanda, que recobrem um período de dez anos dos Juizados Especiais de Niterói e que foram recolhidos nos próprios juizados. Por meio dos dados, temos uma visão das tendências tomadas pelo funcionamento prático dos juizados, a partir da natureza das demandas e de sua alteração no tempo. Esses dados foram complementados com informações recolhidas em entrevistas realizadas com diversos agentes do sistema: conciliadores, advogados, promotores, juízes e, naturalmente, as partes em litígios, réus e vítimas. O cotejamento entre os dados estatísticos e os relatos dos agentes diretamente envolvidos nas atividades dos juizados nos forneceu um rico material de análise, o qual permite observar claramente, conforme esperamos demonstrar, os principais entraves e perspectivas dos Juizados Especiais.

Entre as elites jurídicas brasileiras, as referências históricas mais recentes à criação de um Juizado Especial de Pequenas Causas são encontradas na década de 1980, e o seu marco mais importante é a Lei 7.244, de 7 de novembro de 1984, a qual representou o desdobramento e corolário das discussões sobre a reforma do judiciário no âmbito do Programa Nacional de Desburocratização. Posteriormente, o espírito dessas discussões repercutiria no contexto dos trabalhos constituintes de 1987, na própria Constituição de 1988 e, por fim, ganhariam contornos institucionais com a Lei 9.099, em 1995. Na esteira dessa trajetória, acumulavam-se as experiências dos então chamados Tribunais de Pequenas Causas - primeiramente no Rio Grande do Sul - e as conquistas acumuladas ao longo do tempo pelas organizações de consumidores em todo o país. ${ }^{1}$

A análise desse material orientou a hipótese geral do trabalho, segundo a qual os Juizados Especiais, desde a sua concepção original, gestada nos trabalhos constituintes de 1987-88, passando por sua regulamentação com a lei 9.099/95 e posteriores leis de âmbito estadual, experimentaram um progressivo desvirtuamento dos ideais de sua criação como um tipo de justiça não estatal, mais informal e próxima dos princípios comunitaristas de justiça, e transformaram-se, ao invés disso, em um braço estendido do poder judiciário. A configuração institucional dos Juizados Especiais como instituições progressivamente atreladas ao poder judiciário 
e às respectivas corporações jurídicas se deu, assim, como resultado de inúmeros conflitos e tensões com os quais eles sempre conviveram, desde a sua concepção até a sua implementação.

Com foco na discussão sobre a natureza da legitimidade das decisões e dos procedimentos dos Juizados Especiais, nosso trabalho destaca duas dessas tensões estruturantes da experiência dos juizados: uma, a tensão de culturas legais, resultante do transplante legal de expedientes do modelo de direito responsivo, norte-americano, para um sistema jurídico formalista e legalista, como é o brasileiro; a outra, a tensão entre promover uma justiça relativamente autônoma em relação ao judiciário estatal, marcada pela inovação nas estratégias de abordagem e processamento dos litígios, e ampliar o acesso à justiça estatal, incentivando medidas simplificadoras de ritos e procedimentos judiciais.

Para compreendermos o primeiro aspecto mencionado sobre a experiência dos Juizados Especiais, isto é, a tensão entre culturas legais, a clássica modelagem desenvolvida por Philip Selsnick e Philippe Nonet (2001) para analisar os diferentes tipos de ordenamentos jurídicos nos oferece um auxílio importante. Existiriam, segundo esses autores, três tipos puros de sistemas jurídicos: o modelo repressivo, o autônomo e o responsivo. Enquanto tipologias, não há correspondência exata desses modelos analíticos com os sistemas jurídicos tais como estes existem concretamente. Os tipos nos ajudam apenas a fixar os traços mais gerais e marcantes de um sistema jurídico empiricamente dado, facilitando-nos, ainda, a compreensão dos processos de mudança e transição entre os tipos postulados. Seguindo esse sistema analítico e classificatório, a tradição do sistema legal brasileiro se enquadraria em um tipo misto daquilo que os autores chamam de ordenamento jurídico repressivo e do ordenamento jurídico autônomo, característico, diga-se, dos sistemas jurídicos latino-americanos. Em síntese, essa tradição mistura ativismo político e altas doses de repressão legal, com a crença em um sistema jurídico derivado do discernimento racional dos legisladores e do julgamento neutro dos juízes. Ambas estas tradições identificáveis no ordenamento jurídico brasileiro, a repressiva e a autônoma, seriam diferentes do modelo que Nonet e Selsnick (2001) chamam de "responsivo" e o qual identificam nas tradições jurídicas da Commom Law inglesa e da Case Law norte-americana. A diferença fundamental entre as tradições repressiva e autônoma, de um lado, e a responsiva, de outro, estaria, segundo esses autores, na maior capacidade do modelo responsivo em atender as demandas por justiça oriundas de definições sociais e políticas circunstanciadas pelos problemas cotidianos das pessoas.

Por seu turno, na tradição do ordenamento jurídico autonomista, formalista e legalista, fazer justiça é, essencialmente, julgar em conformidade com a lei; e há dificuldade de se reconhecer, pelo sistema legal, diferenças sociais, raciais, de gênero e econômicas, ainda que elas possam, em tese, ser consideradas. Na verdade, nessa tradição, quaisquer legislação e ativismo jurídico de magistrados que pressionem no 
sentido de se estabelecerem exceções à regra geral em virtude da consideração de valores ética e moralmente consubstanciados nos julgamentos são considerados como ameaças de fissuras na cláusula formal e racionalista da igualdade entre os cidadãos.

A análise da trajetória dos Juizados Especiais nos oferece um interessante exemplo de choque entre "culturas legais" como resultado daquilo que alguns autores consagraram na literatura especializada como "transplante legal" (NELKEN; FEEST, 2001). Inspirados na experiência norte-americana das chamadas Small Claim Courts (Cortes de Pequenas Causas), em especial as de Nova York, embebidas das culturas jurídicas da Common Law, os Juizados Especiais no Brasil foram se configurando em meio a uma tradição jurídica nacional brasileira, oscilante entre repressiva e racionalista-legalista. Idealizados pelos constituintes, nos trabalhos de 1987, como organismos especiais para a promoção de soluções jurídicas sem a necessária participação direta e efetiva dos agentes estatais, os Juizados Especiais progressivamente se conformaram aos padrões normativos, legalistas e formalistas implementados pelos agentes do poder judiciário estatal.

Ao discutir sobre a efetividade dessa justiça, o nosso trabalho pretende explorar, portanto, a discussão sobre a natureza da legitimidade dos Juizados Especiais.

Disso deriva a segunda tensão conformadora da experiência dos Juizados Especiais a qual queremos analisar: a tensão entre aumentar e facilitar o acesso dos cidadãos à justiça por meios institucionais alternativos ao poder judiciário e simplesmente descongestionar a justiça estatal ao ampliar o espectro da sua atuação pela simplificação de procedimentos. Trata-se de uma discussão importante, por ser a ponta de um amplo problema formado não apenas pelo confronto de ideias e filosofias distintas sobre o ordenamento jurídico - entre uma perspectiva mais cidadã e civilista e outra legalista e estatizante -, mas por uma luta silenciosa, porém impiedosa das corporações formadas em torno dos interesses do judiciário estatal contra as formas comunitaristas e cívicas de prestação de serviços jurisdicionais. Essa tensão interage com a anterior, porque ambos os processos descrevem a mesma lógica de imposição de uma cultura legal formalista, estatista e corporativista, e dos seus padrões burocráticos e meritocráticos. Ambas as tensões remetem aos esforços de monopolização da justiça pelo poder judiciário estatal e suas corporações.

Para a realização deste trabalho, além dos dados quantitativos dos processos instaurados ao longo de quase dez anos de existência dos Juizados Especiais de Niterói, fizemos um trabalho de avaliação qualitativa do funcionamento desses juizados por meio da realização de 32 entrevistas, realizadas entre os anos de 2005 e 2008, e do acompanhamento particularizado de 5 casos.

As audiências nos Juizados Especiais são públicas. Isso tornou relativamente fácil o acesso a elas, possibilitando a apuração qualitativa do ambiente estudado a partir da observação das audiências, que, colocadas em uma escala hierárquica, de acordo com a Lei 9.099/95, dividiam-se respectivamente em Conciliações e em Instrução e 
Julgamento. Após um número satisfatório de depoimentos de pessoas que solicitavam ou eram intimadas pelos Juizados Especiais a comparecerem em tais audiências, esforçamo-nos em coletar as opiniões daquelas que operavam esse dispositivo legal.

O trabalho de natureza qualitativa prosseguiu com o acompanhamento pós-julgamento de um dos casos: o de D. contra o condomínio Y. Nosso objetivo, então, foi identificar como a experiência de leigos (partes em litígio) e de profissionais nos juizados alterou ou cristalizou as noções de justiça e do justo e a maneira como isso influenciou ou não as suas vidas cotidianas. A análise desse caso, segundo a nossa perspectiva, ilustra os atuais impasses e desafios vividos pelos Juizados Especiais.

Em todas as entrevistas, nós procuramos avaliar os impactos da experiência nos Juizados Especiais na vida cotidiana das pessoas.

\section{A TENSÃO ENTRE “CULTURAS LEGAIS": A LEGITIMIDADE RACIONAL LEGAL E A LEGITIMIDADE RESPONSIVA}

Como dissemos, o pano de fundo de nossa discussão é a reflexão sobre a natureza da legitimidade das decisões proferidas nos Juizados Especiais, notadamente em um contexto de reformas políticas e afirmação das instituições democráticas brasileiras. Não se trata, naturalmente, de uma discussão acerca da existência de legitimidade ou não nas decisões desses juizados. Sem dúvidas, como a farta produção de feitos dos Juizados Especiais demonstra, o seu funcionamento deu novo vigor às ações do judiciário, permitindo aos seus agentes a ostentação de um vultoso número de atendimentos e serviços jurisdicionais prestados anualmente, que têm servido como a vitrine mais bem iluminada e conhecida dos dispositivos institucionais instaurados com o suporte legal da Constituição de 1988 e que, segundo a impressão corrente, teriam ampliado e facilitado o acesso de um maior número de pessoas à justiça, por um número maior de motivações.

Tal impressão é confirmada pelas estatísticas que mostram um número crescente de processos instaurados e de feitos realizados, da ordem de milhares anualmente (ver Gráfico 1), indicando que, independente da natureza da ação, a maior demanda pelos serviços jurisdicionais dos Juizados Especiais se dá como resultado da afirmação da sua legitimidade junto à população, que tem acorrido às suas cortes em busca de decisões juridicamente perfeitas.

Entretanto, se quisermos uma análise mais qualitativa da natureza dessa legitimidade - se ela deriva, por hipótese, da assunção, por conciliadores, advogados e juízes, de padrões de justiça comunitários e civilistas, ou se, ao contrário, a sua legitimidade está ancorada exclusivamente no amparo e na reprodução das regras e dos procedimentos da cultura legal da justiça estatal -, é necessário ir além dos dados agregados e examinars alguns aspectos da cultura jurídica que tem se desenvolvido sob tal tensão. 
O conceito de "cultura legal" utilizado aqui para a compreensão desse fenômeno é inspirado na teoria de Lawrence Friedman $(1975,1998)$ e subentende, tal como esse autor, que a "cultura legal" é um conjunto variado de expressões, compreensões e usos da lei e do direito no sentido mais amplo, os quais são particularizados pelas sociedades e dentro delas pelos diversos grupos sociais. O conceito de cultura legal, segundo o autor, descreve um dispositivo sócio-cultural de interação das relações sociais no direito, qualificando a tese mais geral dessa disciplina acerca da influência e da existência de determinações recíprocas entre as relações sociais e o direito. Como explica Friedman, o conceito de cultura legal demonstra a etapa específica do processo de configuração institucional do sistema jurídico resultante da fricção entre as relações sociais cotidianas e as leis que são criadas em seu contexto. Supõe-se, então, a existência de uma articulação funcional e não problemática entre os diferentes níveis da vida social. Em uma equação: relações sociais $\rightarrow$ cultura jurídica $\rightarrow$ direito.

Nossa apropriação do conceito de cultura legal introduz a mediação do conceito de legitimidade, para entendermos como se constituem e se afirmam, no interior de uma sociedade, as diferentes culturas legais. Nós acreditamos que o conceito de legitimidade permite introduzir na análise das culturas legais de Lawrence Friedman um dispositivo conceitual para pensarmos a ação de atores nas arenas públicas e nas instâncias decisórias e como eles expressam aí os seus interesses e atuam no sentido de impor os seus pontos de vista. Em adição, portanto, ao modelo imaginado por Friedman, a nossa análise introduz a variável legitimidade como novo elemento constitutivo do processo de construção social do direito, do qual a “cultura legal” ou “jurídica” é uma das expressões. Em resumo, nós pensamos que as interações sociais e o complexo de expectativas recíprocas dos agentes conformam ações referenciadas nos costumes e na lei, constituindo culturas legais eventualmente concorrentes. Este campo tensionado entre a adequação de ações a expectativas consolidadas em culturas legais seleciona, por intermédio de uma multiplicidade de recursos de poder, materiais e cognitivos, que são mobilizados pelos agentes desigualmente, conferindo-lhes um poder desigual nas disputas pela legitimidade dos seus próprios padrões culturais. Em uma equação: relações sociais $\rightarrow$ culturas jurídicas $\rightarrow$ legitimidade $\rightarrow$ direito.

Servindo-nos da classificação de Friedman $(1975,1998)$ e do modelo de Selsnick e Nonet (1989), a hipótese geral que orienta este trabalho é a de que a recepção jurídica dos Juizados Especiais se insere nesse campo de tensões constitutivas do padrão de legitimidade dos processos e das decisões judiciais no Brasil. Especificamente, no campo das tensões representadas pelo choque entre um sistema jurídico tradicionalmente legitimado por uma cultura legal misturada, entre repressiva e autônoma, de corte europeu continental, e um expediente jurídico típico da cultura legal "responsiva" dos ordenamentos jurídicos norte-americano e inglês. Nesse embate conflituoso entre culturas legais divergentes, o que a experiência dos Juizados Especiais tem 
demonstrado é que os interesses corporativos dos operadores do direito, especialmente dos magistrados, mas também dos advogados e promotores, têm prevalecido sobre os esforços por uma maior democratização da prestação de serviços jurisdicionais. A legitimidade das suas decisões tem cada vez mais se afastado de um ideal de justiça mais comunitarista e aderente aos padrões morais da sociedade e se assentado na crença na autonomia da lei e do direito, frente aos [em detrimento de] critérios políticos e morais de decisão.

Com isso, observa-se claramente no processo de implementação dos Juizados Especiais um movimento crescente de formalização dos procedimentos e de captura do processo decisório dessas instâncias pelas corporações jurídicas estatais e paraestatais.

\section{JUIZADOS ESPECIAIS: CENTROS DE TRIAGEM E BALCÕES DE RECLAMAÇÃO OU UMA ALTERNATIVA AO JUDICIÁRIO FORMAL?}

A segunda tensão conformadora da experiência dos Juizados Especiais no Brasil é definida, como nós dissemos, pela concorrência de propósitos entre os formuladores da legislação (constituintes) e os executores das ações de criação e desenvolvimento institucional desses juizados (as corporações de magistrados, promotores e advogados, especialmente), isto é, aumentar e facilitar o acesso dos cidadãos à justiça por meios alternativos ao poder judiciário ou, então, simplesmente descongestionar o judiciário estatal, promovendo uma espécie de triagem entre ações judiciais simples e possíveis de serem resolvidas sem a intervenção direta do juiz e aquelas complexas, com todas as exigências de procedimentos do sistema estatal.

Essa mesma tensão de propósitos entre ampliar o acesso à justiça por intermédio de expedientes e procedimentos alternativos à justiça estatal ou simplesmente descongestionar a justiça comum estatal, operando um sistema de filtragem das ações abrigadas pelo judiciário, não é exclusiva do Brasil. Ela esteve presente, por exemplo, nas discussões que acompanharam a criação das Small Claim Courts norteamericanas, cujas propostas fundamentais, como a mudança nos métodos de resolução dos conflitos, com substituição do modelo adversarial pela mediação, a ser realizada por pessoa diferente do juiz, inspiraram a criação dos Juizados Especiais brasileiros. Em ambas as experiências, a conciliação oferecia às partes maiores oportunidades de se expressar, sem a necessária participação de advogados, e a possibilidade de encontrar uma resolução amigável para a disputa, através de um acordo.

No caso norte-americano, no entanto, em comparação com o brasileiro, essas tensões apresentavam um sinal trocado, resultado das distintas tradições legais de um e outro país. Nos Estados Unidos, de acordo com Christine Harrington (1985), tanto os movimentos de reforma judicial do início do século XX, que deram origem a uma extensa e diversificada rede de justiça municipal, quanto os da década de 1970 
tinham explícita e implicitamente objetivos de organização do sistema de justiça em bases mais centralizadas e com procedimentos mais homogêneos e formalizados.

Harrington também chama atenção para outro aspecto relacionado ao surgimento das Small Claim Courts, inserindo-as no contexto de unificação do sistema judicial norte-americano. O final do século XIX e início do século XX, argumenta a autora, foi um período marcado por críticas dirigidas ao modelo de prestação de justiça da época, a Justiça de Paz. A ineficiência do sistema, dada, sobretudo, pela lentidão, era, segundo os reformadores, resultado da falta de administração. A solução seria a extinção das Justiças de Paz e a montagem de cortes municipais, organizadas de acordo com o modelo gerencial. Essas propostas, formuladas no mesmo período em que ocorria a institucionalização da profissão jurídica no país, foram defendidas pelo "movimento das cortes municipais", que pregava a reorganização e estratificação do trabalho judicial. Na década de 1970, a discussão envolvendo as Small Claim Courts foi marcada por propostas de reformas, as quais redefiniram seus objetivos. Considerava-se que, embora o objetivo de criação de uma justiça eficiente (rápida e barata) já houvesse sido alcançado, esse sistema não era igualitário e acessível a todos. Os pobres participavam apenas na condição de réus e, normalmente, perdiam. Era esse o ponto que as reformas afirmavam querer atacar (HARRIGTON, 1985). ${ }^{2}$

Uma terceira expressão da mesma tensão entre diversificar e aumentar o acesso à justiça pela criação de instituições alternativas ao poder judiciário ou criar expedientes simplificadores de acesso à justiça estatal é a que verificamos nos países da Europa Ocidental. Neste continente, respeitando-se, naturalmente, as tradições e idiossincrasias de cada país, tal tensão esteve marcada em sua essência pela concorrência das legitimidades legalista e estatal - "autônoma” -, por um lado, e dos novos padrões responsivos de justiça, introduzidos pelas políticas públicas de welfare state durante todo o correr do século XX, por outro. Uma visão panorâmica da resposta europeia a essas questões pode ser detectada, por exemplo, pelo Projeto Florença, pesquisa desenvolvida por Mauro Cappelletti e Bryant Garth (1988). Segundo o que constataram os autores, as barreiras encontradas pela sociedade para a solução de suas demandas seriam: a) custas judiciais (remuneração de juízes e serventuários, além das despesas processuais), que se fazem sentir mais nas pequenas causas, em que as custas podem exceder o valor da demanda; b) possibilidades das partes (conhecimento suficiente do direito para propor ação ou defesa, despesas com advogados e manutenção de um processo longo etc.); e c) tutela judicial dos interesses difusos, característicos da economia quando "ou ninguém tem direito a corrigir a lesão a um interesse coletivo, ou o prêmio para qualquer indivíduo buscar essa correção é pequeno demais para induzi-lo a tentar uma ação" (CAPPELLETTI; GARTH, 1988, p. 26).

Segundo a mencionada pesquisa, uma das formas de se eliminarem tais barreiras seria o estímulo aos juízos especializados em pequenas causas, os quais constituem a 
chamada "terceira onda de acesso à justiça”, em seguida à inclusão dos pobres (primeira onda) e ao reconhecimento judicial das demandas coletivas (segunda onda).

No Brasil, a política de reforma do Estado iniciada pelo antigo Ministério da Desburocratização no contexto da redemocratização, na década de 1980, demandou a reestruturação do judiciário informal. A primeira experiência ocorreu no Rio Grande do Sul, em 1983, onde foi testado pela primeira vez um Conselho Informal de Conciliação. Tal iniciativa estimulou a regulamentação federal dos Juizados de Pequenas Causas (Lei n ${ }^{\circ} 7.244 / 84$ ), que passaram a ter um procedimento diferenciado para demandas de pequeno valor.

Esses órgãos foram inseridos na Constituição de 1988 (artigo 98, I), prevendo uma composição por três agentes, alternativamente: juiz togado, juiz leigo e conciliador. ${ }^{3}$ Em 1995, os Juizados de Pequenas Causas foram substituídos pelos Juizados Especiais (Lei $n^{\circ}$ 9.099). Em seu artigo $7^{\circ}$, a nova lei dispõe que "os conciliadores e Juízes leigos são auxiliares da Justiça, recrutados, os primeiros, preferentemente, entre os bacharéis em Direito, e os segundos, entre advogados com mais de cinco anos de experiência". Com isso, a Lei dos Juizados Especiais qualifica como leigo aquele que não é investido por meio de concurso público para a magistratura. ${ }^{4}$

Apesar de ser de competência privativa da União legislar sobre direito processual, há a competência concorrente da União e dos Estados para legislar sobre a “criação, funcionamento e processo do juizado de pequenas causas" (artigo 24, $\mathrm{X} / \mathrm{CRFB}$ ). Tal dispositivo permitiu uma variedade considerável de configurações dos Juizados Especiais nos diferentes estados, embora limitada pelas diretrizes da lei federal. No estado do Rio de Janeiro, o funcionamento dos Juizados Especiais é regulamentado pela Lei $n^{\circ} 2.556 / 96$, a qual foi recentemente alterada pela Lei $n^{\circ}$ 4.578/05. Agora, conforme o seu artigo 12 atual, "os conciliadores e juízes leigos serão selecionados por concurso público, os primeiros, preferencialmente, entre bacharéis e bacharelandos em Direito, e os segundos, entre advogados [...]”. E, ainda, a lei reformadora dispõe que "a função de juiz leigo [...] será exercida por alunos da Escola da Magistratura do Estado do Rio de Janeiro, na forma disposta em Regulamento, vedado seu exercício por serventuários do Poder Judiciário do Estado do Rio de Janeiro”.

Consideradas em seu conjunto, essas mudanças legais e mais outras tantas evidências da incorporação da cultura formalista ao funcionamento dos Juizados Especiais demonstram o caráter agressivo da atuação da corporação dos operadores do direito no sentido de desfigurar a concepção e os ideais civilistas e comunitaristas do legislador constitucional.

Além do problema atual da restrição da função de juiz leigo aos estudantes da Escola da Magistratura do Estado do Rio de Janeiro (EMERJ), o atual sistema legal limita consideravelmente os seus poderes no processo. O juiz leigo apenas propõe a conciliação (Lei 9.099/95, artigos 21 e 22) e, se houver consenso entre as partes, 
servirá como árbitro (artigo $24, \S 2^{\circ}$ ), já que a sua decisão fica condicionada à homologação pelo juiz togado (artigos 26 e 40).

Claramente, a tensão entre promover e ampliar as experiências alternativas ao judiciário estatal ou simplesmente descongestionar a justiça comum por meio de um expediente de triagem foi estabilizada, com o predomínio da cultura formalista e estatal e o claro avanço dos tentáculos do poder judiciário sobre os Juizados Especiais. Mais fortes do que as intenções democratizantes dos constituintes, que acenaram com a possibilidade de experimentos judiciais mais civilistas e comunitaristas, foram os interesses corporativistas de juízes e advogados, na medida em que estes conseguiram restaurar, em legislações complementares, algumas prerrogativas de monopólio dessas corporações. O esvaziamento do conteúdo cívico dos Juizados Especiais gerou como resultado a neutralização das possibilidades de desenvolvimento de experiências inovadoras de justiça, alternativas ao Estado e à sua carga opressiva e repressiva, mobilizada por grupos instalados nas suas instituições e seus lobbies usuais. Atuando de forma cada vez mais burocratizada e com decisões padronizadas, os Juizados Especiais transformaram-se em balcões de triagem de causas que devem ou não ser apreciadas pela justiça estatal "comum” e aquelas que ficarão simplesmente como um registro de reclamações do pequeno consumidor diante de grandes litigantes.

\section{JUIZADOS ESPECIAIS: O PROBLEMA NA PRÁTICA}

Os Juizados Especiais Cíveis e Criminais de Niterói foram criados e regulamentados pela Lei 2.556, de 21 de maio de 1996. Em seu artigo primeiro, a referida lei instituía um "Sistema Estadual de Juizados Especiais Cíveis e Criminais" para conciliação, julgamento e execução, pelo poder judiciário, de causas cíveis e infrações penais de menor potencial ofensivo. Essa lei, como nós dissemos, passou por algumas modificações, tendo sido a mais recente delas a Lei 4.578/05, que alterou especialmente a forma de seleção dos conciliadores e juízes leigos, atribuindo maiores prerrogativas ao presidente do Tribunal de Justiça.

$\mathrm{Na}$ época da instalação da Lei 2.556/96, eram apenas dois os juizados criminais de Niterói e dois os de natureza cível, o I e o II Juizado Especial Cível de Niterói e o I e o II Juizado Especial Criminal, respectivamente. Quase dez anos depois, em 2005, os juizados permaneciam em igual número e continuavam localizados no mesmo segundo andar do prédio da Rodoviária Municipal, próximo ao centro da cidade. Somente no ano de 2006 foram criados os Juizados Especiais Criminais e Cíveis da Região Oceânica.

Na sede da Estação Rodoviária, onde foi feita a pesquisa qualitativa, as instalações pareciam improvisadas para o seu tipo de uso, mesmo depois de passados dez anos da sua inauguração, e, segundo um dos conciliadores entrevistados, aquele não seria 
o ambiente ideal para a realização da conciliação, dados o desconforto e a exiguidade dos móveis e das instalações.

Nos Juizados Especiais Cíveis predominam as matérias consumerísticas relacionadas a reclamações contra empresas prestadoras de serviços públicos, especialmente concessionárias, mas também bancos, financeiras, grandes lojas, de tal sorte que a grande maioria das ações se concentra em meia dúzia de empresas.

Nesse tipo de configuração da demanda, a clivagem de Galanter adotada por Cappelletti e Garth (1988), a predominância do conflito entre litigantes "eventuais" e litigantes "habituais" nos parece bastante adequada para entender a situação:

O professor Galanter desenvolveu uma distinção entre o que ele chama de litigantes 'eventuais' e 'habituais', baseado na freqüência de encontros com o sistema judicial. Ele sugeriu que esta distinção corresponde, em larga escala, à que se verifica entre indivíduos que costumam ter contatos isolados e pouco freqüentes com o sistema judicial e entidades desenvolvidas, com experiência judicial mais extensa. As vantagens dos 'habituais', de acordo com Galanter, são numerosas: 1) maior experiência com o Direito possibilita-lhes melhor planejamento do litígio; 2) o litigante habitual tem economia de escala, porque tem mais casos; 3) o litigante habitual tem oportunidades de desenvolver relações informais com os membros da instância decisora; 4) ele pode diluir os riscos da demanda por maior número de casos; e 5) pode testar estratégias com determinados casos, de modo a garantir expectativa mais favorável em relação a casos futuros. Parece que, em função dessas vantagens, os litigantes organizacionais são, sem dúvida, mais eficientes que os indivíduos. (p. 25)

No caso dos Juizados Especiais, essa observação é inescapável quando se observa que a quase totalidade dos litígios, para vários períodos de tempo considerados, resume-se a milhares de reclamantes de um lado do balcão e uma dezena de empresas do outro lado, responsabilizadas pela ofensa a direitos.

O analista judiciário J., com ampla experiência nos Juizados Especiais, conta que esse tipo de demanda por ressarcimento de danos e prejuízos provocados por serviços ineficientes e muitas vezes não prestados, bem como por indenizações por danos morais associados ao prejuízo material - demanda concentrada, repita-se, na atuação de poucas empresas -, ensejou a criação do chamado "expressinho", que adotava um procedimento padrão para o julgamento dos litígios contra determinadas empresas, notadamente as prestadoras de serviços de telefonia e bancos.

Dessa forma, nas relações de consumo, os Juizados Especiais passaram a absorver vários litígios que antes não eram devidamente apreciados pelo judiciário, em razão da desproporcionalidade entre custas judiciais e possíveis benefícios. Além 
disso, como há limitação legal para apreciação de causas trabalhistas, familiares e fazendárias pelos Juizados Especiais, existe uma predominância das matérias relacionadas ao consumo. Surge, assim, no meio jurídico, uma associação entre cidadania, Juizados Especiais e proteção ao consumidor, construída a partir de marcos legais dos anos 1990: o Código de Defesa do Consumidor (Lei 8.078/90) e os Juizados Especiais (Lei 9.099/95).

$\mathrm{Na}$ prática, entretanto, os Juizados Especiais acabaram absorvendo uma tarefa que deveria ser atribuída às agências reguladoras: a fiscalização das concessionárias de serviços públicos. Segundo os dados estatísticos do Tribunal de Justiça do Rio de Janeiro relativos ao mês de novembro de 2007, os dez maiores réus nos juizados são empresas de: telefonia - Telemar/Oi $\left(1^{\circ}\right)$, Vivo $\left(5^{\circ}\right)$ e Tim $\left(7^{\circ}\right)$-; energia elétrica Ampla $\left(2^{\circ}\right)$ e Light $\left(3^{\circ}\right)$-; e instituições bancárias - Itaú $\left(4^{\circ}\right)$, Banco do Brasil $\left(6^{\circ}\right)$, Unibanco $\left(8^{\circ}\right)$, Bradesco $\left(9^{\circ}\right)$ e Itaucard $\left(10^{\circ}\right) .{ }^{5} \mathrm{Se}$, num primeiro momento, o número alto desses tipos de ações pode parecer uma ampliação do acesso à justiça, garantindo uma tutela jurisdicional antes inimaginável, a depuração do fenômeno nos indica, porém, que a costumeira presença das mesmas empresas, prestadoras dos mesmos serviços, significa na realidade que as lesões aos direitos dos consumidores são rotineiras e que as decisões tomadas no âmbito dos Juizados Especiais não têm provocado os necessários efeitos dissuasórios da atuação lesiva de tais empresas. Ainda como efeito dessa distorção, a presença constante das mencionadas empresas acaba congestionando os cartórios, acarretando maiores custos operacionais (funcionários técnico-administrativos e adiamento de audiências). ${ }^{6}$

\section{DESVIRTUAMENTO DOS JUIZADOS ESPECIAIS: O CASO DE NITERÓI}

O conjunto dos dados recolhidos até o momento revela um aumento exponencial das demandas pelos serviços dos Juizados Especiais, em Niterói. Na esfera cível, os mais recorrentes são os casos ligados às relações de consumo, sendo menor o número de processos envolvendo pessoas físicas. Os conflitos de vizinhança, por serem mais raros, nem chegam a ser catalogados segundo os critérios oficiais, restando diluídos em outros critérios. Como se verá, esse dado, ou a ausência dele, é indicativa do esvaziamento do conteúdo mais comunitarista das funções dos juizados.

Tabela 1 - Processos nos Juizados Especiais Cíveis de Niterói de 1997 a 2005 (Fonte: <http: / /www.tj.rj.gov.br>)

\begin{tabular}{|c|c|c|c|c|c|c|c|c|c|}
\hline NATUREZA DA DEMANDA & 1997 & 1998 & 1999 & 2000 & 2001 & 2002 & 2003 & 2004 & 2005 \\
\hline DIREITO DO CONSUMIDOR & 513 & 1.980 & 4.939 & 2.868 & 11.029 & 12.858 & 19.000 & 12.794 & 8.716 \\
\hline $\begin{array}{l}\text { ARRENDAMENTO RURAL/ } \\
\text { PARCERIA AGRÍCOLA }\end{array}$ & 2 & 0 & 5 & 4 & 0 & 3 & 0 & 0 & 0 \\
\hline
\end{tabular}




\begin{tabular}{|c|c|c|c|c|c|c|c|c|c|}
\hline COBRANÇAS DE CONDOMÍNIO & 11 & 12 & 57 & 1 & 7 & 6 & 4 & 1 & 0 \\
\hline $\begin{array}{r}\text { DANOS EM PRÉDIO URBANO } \\
\text { OU RÚSTICO }\end{array}$ & 25 & 23 & 25 & 7 & 2 & 1 & 1 & 0 & 0 \\
\hline $\begin{array}{r}\text { DANOS EM ACIDENTE } \\
\text { DE AUTOMÓVEIS }\end{array}$ & 183 & 219 & 174 & 123 & 74 & 130 & 130 & 25 & 40 \\
\hline $\begin{array}{r}\text { SEgURO POR ACIDENTE } \\
\text { DE VEÍCULOS }\end{array}$ & 18 & 3 & 18 & 10 & 15 & 5 & 3 & 0 & 0 \\
\hline $\begin{array}{r}\text { COBRANÇA DE HONORÁRIOS } \\
\text { PROFISSIONAIS }\end{array}$ & 38 & 56 & 44 & 51 & 75 & 57 & 53 & 71 & 39 \\
\hline $\begin{array}{r}\text { OUTROS CASOS PREVISTOS } \\
\text { EM LEI }\end{array}$ & 828 & 1313 & 781 & 1200 & 23 & 14 & 20 & 2 & 0 \\
\hline DESPEJO PARA USO PRÓPRIO & 15 & 29 & 10 & 21 & 20 & 10 & 13 & 16 & 16 \\
\hline $\begin{array}{r}\text { EXECUC̣ÃO DE TÍTULO } \\
\text { EXTRAJUDICIAL }\end{array}$ & 302 & 490 & 431 & 474 & 479 & 411 & 567 & 464 & 285 \\
\hline EXECUÇÃO DE TÍTULO JUDICIAL & 2 & 94 & 55 & 13 & 11 & 10 & 10 & 26 & 57 \\
\hline MEDIDAS CAUTELARES & 30 & 233 & 682 & 380 & 18 & 27 & 38 & 25 & 6 \\
\hline MONITÓRIAS & 83 & 102 & 79 & 14 & 7 & 3 & 1 & 0 & 0 \\
\hline $\begin{array}{r}\text { OUTRAS COM VALOR DE } \\
\text { ATÉ } 40 \text { SALÁRIOS MÍNIMOS }\end{array}$ & 990 & 3.646 & 4.186 & 4.339 & 6.209 & 4.516 & 309 & 309 & 185 \\
\hline POSSESSÓRIAS & 7 & 28 & 104 & 9 & 13 & 8 & 8 & 14 & 2 \\
\hline PrecatóRIAS & 343 & 381 & 666 & 793 & 845 & 1.063 & 1.756 & 1.842 & 1.738 \\
\hline Cobrança & - & - & - & - & - & 203 & 859 & 683 & 591 \\
\hline RESSARCIMENTO/INDENIZAC̣ÃO & - & - & - & - & - & 1358 & 8207 & 5939 & 5.892 \\
\hline TOTAL & 3.390 & 8.609 & 12.256 & 10.307 & 18.827 & 20.683 & 30.979 & 22.211 & 17.567 \\
\hline
\end{tabular}

Gráfico 1 - Total de feitos por ano, de 1997 a 2005, do Juizado Especial Cível (Fonte: <http: / /www.tj.rj.gov.br>)

TOTAL DE FEITOS

$\left.\begin{array}{r}35000 \\ 30000 \\ 25000 \\ 20000 \\ 15000 \\ 10000 \\ 5000\end{array}\right]$

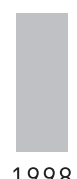

1998

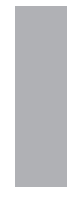

1999

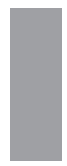

2000

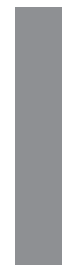

2001

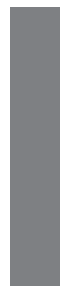

2002

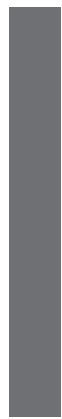

2003

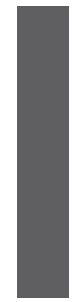

20042005 
Os dados tanto da Tabela 1 quanto do Gráfico 1, relativos à natureza das demandas, confirmam o que nós dissemos antes, isto é, que elas estão concentradas no direito do consumidor e nas ações de ressarcimento e indenizatórias. Ou seja, se considerarmos que as ações indenizatórias e de ressarcimento estão relacionadas, em sua maioria, por origem ou derivação, às ações de consumo, temos que, em 2007, por exemplo, as questões consumerísticas mobilizaram cerca de $80 \%$ dos trabalhos realizados nos Juizados Especiais Cíveis de Niterói.

O comportamento semelhante das curvas desses dois tipos de ações (Gráficos 2 e 3) confirmam a conexão entre ambas.

Gráfico 2 - Litígios relacionados ao direito do consumidor, de 1997 a 2007 (Fonte: <http://www.tj.rj.gov.br>)

\section{DIREITO DO CONSUMIDOR 1997-2007}

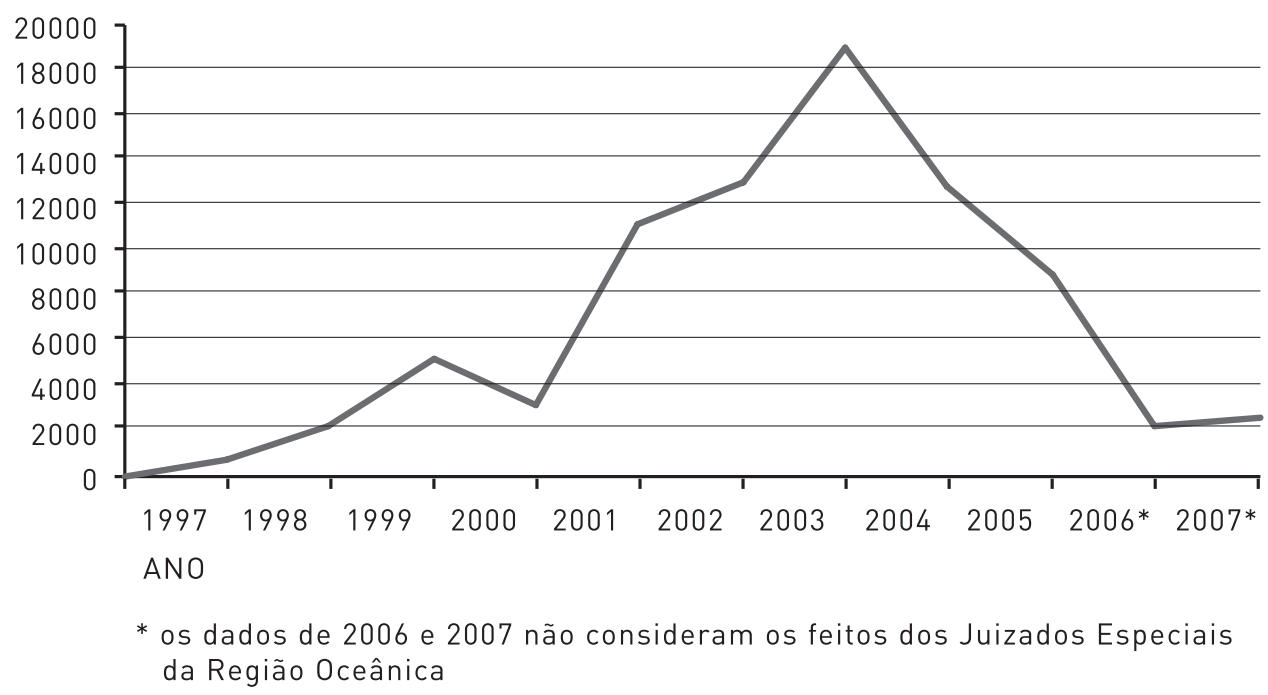


Gráfico 3 - Litígios relacionados ao pedido de ressarcimento e direito do consumidor, de 1997 a 2007 (Fonte: <http: / /www.tj.rj.gov.br>) ${ }^{1}$

RESSARCIMENTO/INDENIZAC̣ÃO 1997-2007

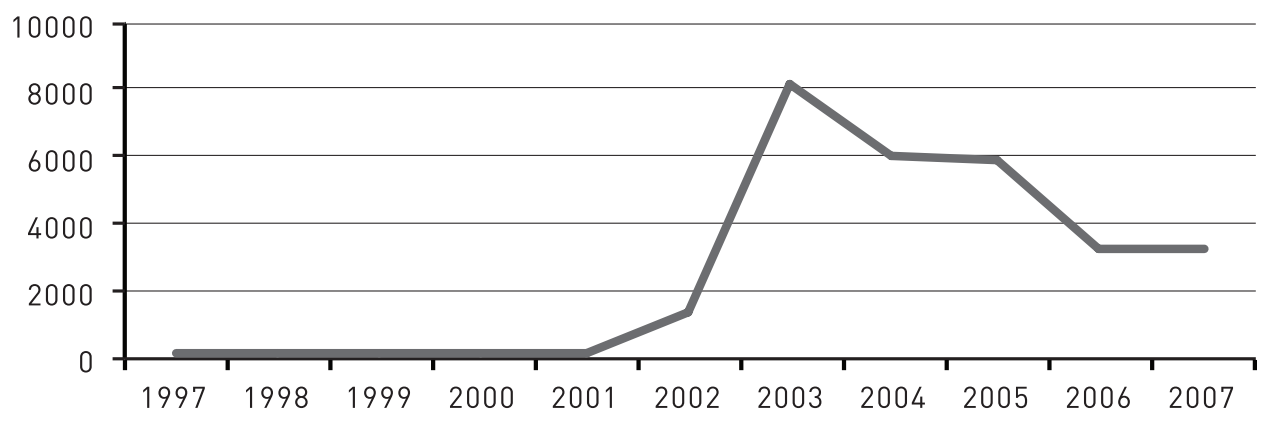

Outro aspecto que ressalta no conjunto desses dados é que, embora o escopo das ações impetradas nos juizados seja diversificado, comprovando o largo espectro de problemas que podem ser legalmente apreciados por tais instâncias, elas estão concentradas em poucos tipos de ações.

Um juiz do Juizado Especial Cível de Niterói entrevistado em nossa pesquisa traduz de forma quase impaciente a sua impressão sobre este viés consumerístico apontado pelo conjunto de dados relativos às ações impetradas:

É sempre a lei de defesa do consumidor. É a mais recorrente. Mas o problema é que as pessoas vêm pedindo sempre o dano moral e elas sempre entram com o patamar máximo do dano moral. Está meio banalizado isso. As pessoas querem mais dinheiro, estão vindo no judiciário por isso. Qualquer coisa: pisa no pé, quebra o pé, querem mil reais. Telefone também. Telefone, eles pedem coisas absurdas. Claro que há falhas no serviço, mas eles não aceitam, por exemplo, uma indenização de dois salários, sempre querem dez, quarenta salários.

Este dado, por si só, revela um dos aspectos da legitimidade dos Juizados Especiais que merecem reflexão. As ações de consumo contra as empresas de telefonia, e contra outras concessões de serviços públicos, como energia elétrica, e, ainda, serviços bancários, estão entre as mais demandadas pelos litigantes. Essas ações, segundo as informações de juízes e conciliadores, atingem pessoas de diversos níveis de renda e social. Como afirma um dos conciliadores entrevistados:

Aqui é muito variado. A gente vê gente tipo ex-juízes recorrendo ao 
Juizado Especial e você vê gente analfabeta, varia muito.

Ou, ainda, segundo a avaliação de outro conciliador:

No juizado, só pode acima de 18 anos. Mas é variado também, tem de tudo. Principalmente, essas empresas de telefonia, essas concessionárias de serviço público, elas prestam serviço para toda a sociedade. Então vai de 18 a 70 anos. É um leque muito grande.

Subtende-se dessa relação vivida às turras entre, de um lado, os conciliadores e juízes e, de outro, as ações consumerísticas que capturam a quase totalidade dos esforços dos Juizados Especiais, que ela é de mútua serventia para os agentes envolvidos. Para as pessoas, de maneira geral, é conveniente e eficaz demandar a justiça para resolver seus problemas de má prestação de serviços e ainda arriscar o recebimento de uma indenização; esse tipo de demanda vem tanto do rico quanto do pobre. Pelo viés do juiz e do staff da justiça especial (conciliadores, advogados, promotores), essa demanda social de justiça legitima as ações e as decisões do Juizado Especial.

O sentimento contraditório entre a crítica ao excesso de litígios relacionados ao consumo e a aceitação comportada dessa tarefa como contrapartida da indispensável legitimação da atuação dos Juizados Especiais, pode ser percebido claramente na fala do juiz. Como afirma o juiz do Juizado Especial Cível de Niterói (o mesmo que reclamava do excesso de litígios relacionados às prestadoras de serviços públicos):

[...] a lei do consumidor advém até de uma determinação constitucional. É para facilitar, é para reduzir a diferença hipossuficiente do consumidor em face das grandes empresas. Ela dá vantagens ao consumidor. Tem que ter mesmo vantagens, até mesmo em função da responsabilidade, que é a responsabilidade objetiva em termos das práticas abusivas que essas empresas às vezes fazem. A propaganda enganosa. E se a propaganda também tem alguma cláusula restritiva de direito do consumidor tem que vir expressa e clara para o consumidor poder entender. São esses contratos de adesão: se chegam com um atraso enorme, o consumidor vai lá e assina. Então tem que fazer a interpretação dessas cláusulas.

Logo em seguida, moto contínuo, ele desqualifica a mesma demanda da seguinte forma:

As pessoas geralmente têm uma noção de que foram lesadas - 'ah, eu não estou gostando disso', 'eu não quero, eu não estou aceitando isso'. Às vezes 
as pessoas chegam aqui sem condições; elas fazem o pedido, chegam no juiz para fazer instrução sem advogado, sem defensor público, sem condições de pagar. Mas você tem que ver também a postura do juiz. O juiz não pode ser também, ao mesmo tempo, julgador e advogado da parte. Porque aí você também não pode quebrar um outro princípio do direito que é o contraditório e a imparcialidade, entendeu? O juiz tem sempre que trabalhar com princípios, com parâmetros.

É possível imaginar que sem ações contra as operadoras de telefonia e eletricidade, por exemplo, caso as agências reguladoras assumissem a integridade das suas funções fiscalizadoras, e não apenas reguladoras, o montante dos serviços apresentados à sociedade pelos Juizados Especiais se reduziriam em cerca de $80 \%$ anuais. O impacto dessa redução expressiva da quantidade de feitos dos Juizados, frequentemente utilizada pelos juízes para invocar a extensão e a legitimidade dos seus serviços junto aos seus jurisdicionados, repercutiria seguramente nas pretensões e demandas desses institutos jurídicos frente aos demais órgãos do judiciário, afetando-os desfavoravelmente na distribuição interna de poder, especialmente dos magistrados diretamente envolvidos em seu funcionamento e sua expansão.

Em nosso ponto de vista, a redução dessa demanda possibilitaria aos Juizados Especiais experimentar com mais intensidade todas as possibilidades de resolução de conflitos que foram originalmente oferecidas pela lei que os criou.

\section{OS CONFLITOS DE VIZINHANÇA: SEM LUGAR PARA RECLAMAR}

Poucas foram as causas pesquisadas que efetivamente possuíam a natureza de conflito de vizinhança. Quatro casos serão destacados, por representarem bem o confronto entre um conflito tipicamente local e a estrutura burocrática do Juizado Especial.

\section{I CASO $\mathrm{N}^{\mathrm{O}}$ OI}

Uma moradora ingressa com ação em face de condomínio cuja síndica autorizara a utilização do espaço comum de moradores como garagem, incomodando o sossego da autora. Questionada sobre o conflito, esta assim expõe:

O fato de a síndica ter resolvido por conta própria criar um estacionamento ao lado do meu apartamento [...], é um absurdo fazer uma coisa dessas arbitrariamente, sem convocar uma reunião ou coisa do tipo. A partir daí fica um barulho insuportável que atrapalha completamente a minha vida. Não conseguia mais fazer as coisas que fazia normalmente com tranquilidade. Como ela não quis resolver de forma amigável fui na justiça. 
Percebe-se que a questão demanda muito mais um mediador do que um julgador. A ausência do diálogo prévio levou a moradora a provocar o judiciário, o que poderia ter sido facilmente evitado. Como jamais havia participado de um processo, a autora foi orientada por uma amiga a propor a ação no Juizado Especial. Após aguardar por sete horas o início da audiência, a autora diz:

Demorou bastante. Mas, pelo que ouço da justiça nesse país, sinceramente eu até estava preparada para esperar mais do que isso. [O Juizado Especial] não é rápido, mas dizem que é melhor do que a justiça comum. Sinceramente não sei, porque nunca precisei da justiça comum, mas não achei rápido não. A espera é cansativa. Espero não ter que precisar em outros casos.

\subsection{CASO $\mathrm{N}^{\circ}$ o2}

Morador aciona o condomínio porque a mala do seu veículo foi arrombada dentro da garagem do prédio, tendo sido furtados o estepe e um carrinho de bebê.

Também neste caso, o Juizado Especial foi visto como uma instância necessária após a ausência de diálogo. Segundo o morador:

Houve uma tentativa de conversar com o condomínio, mas não deu em nada porque eles se recusaram a reconhecer qualquer responsabilidade pelo que aconteceu, aí tive que buscar a justiça.

Assim como no processo anterior, a imagem negativa ficou por conta da demora no atendimento (seis horas):

É demorado. Pensei que ia ser uma coisa mais rápida, que ia resolver direto. Não achei que fosse na hora porque conheço o serviço público do país, mas realmente não esperava aguardar tanto.

\subsection{CASO $\mathrm{N}^{\mathrm{O}}$ O3}

Inquilino indica seus tios como fiadores do contrato de locação. Como os aluguéis não foram pagos, o proprietário do imóvel cobrou dos parentes, e estes acionaram a sobrinha para reaver o que fora pago. Entrevistada, assim a ré relata o caso:

Meus tios foram fiadores do meu apartamento. Ocorreu um grave imprevisto profissional na minha vida e não tive condição de arcar com o pagamento. Eles como fiadores pagaram pra mim e logo após começaram a me cobrar, mas, se eu não tinha condição há poucos dias, não tenho condição agora. Acho que eles pensaram que eu iria dar calote e entraram com essa ação contra mim. 
Assim como ocorreu nos outros casos, a parte reclama da morosidade, afirmando que o atendimento:

Não foi nada bom, além do desgaste emocional de estar sendo acionada por membros da minha família, o atendimento é demorado, esperei bastante. Depois que fui acionada fui pesquisar sobre os Juizados Especiais e disseram que era pra eles serem rápidos, mas não foi o que vi lá.

Ao contrário dos dois casos anteriores, neste se percebe nitidamente o respeito pela instituição judiciária, sob a ótica da ré:

[...] percebi que não é bom ficar devendo a ninguém. Que a sensação de estar sendo acionada na justiça é horrorosa, agora só vou pegar dívidas que eu possa pagar num tempo muito curto, porque encarar tribunal não é uma coisa boa. Dá muito trabalho, perde muito tempo e suga muito de você. [...] o que me pressionou foi a ideia de estar sendo acionada na justiça, não sei se funciona assim pra todo mundo. Mas a sensação é horrível.

\subsection{CASO No $\mathrm{O}_{4}$}

Compradora de apartamento localizado na praia de Icaraí, bairro da classe média alta de Niterói, ao reformar o imóvel para morar, retirando os toldos para lavagem e conserto, constatou que a parede externa e frontal ao apartamento, na qual os toldos estavam fixados, tinha problemas de fixação porque, segundo o pedreiro contratado para a execução dos serviços, a parede estava "oca”. Poucos dias depois de executado o serviço, um dos toldos se desprendeu, atingindo a janela de um apartamento vizinho. Ao comunicar o ocorrido para a síndica do prédio e dizer que os toldos não estavam bem fixados por problemas na parede externa, a autora, D., foi, segundo disse, instruída pela síndica a comprar parafusos especiais para a execução do serviço. Como os novos parafusos de nada resolveram, D. procurou novamente a síndica e, desta vez, recebeu como resposta a recomendação de que resolvesse por conta própria o problema. Como, no seu entendimento, segundo a interpretação que havia feito do estatuto do condomínio, as áreas externas do prédio eram de responsabilidade do condomínio, e não dos proprietários individualmente, a autora entrou nos Juizados Especiais, orientada por estagiários do escritório de assessoria jurídica da Faculdade de Direito Candido Mendes:

Vi um anúncio de assessoria jurídica gratuita em um jornalzinho da Faculdade de Direito Candido Mendes. Lá me informaram que o caminho seria o Juizado Especial. 
No Juizado Especial:

[...] marcaram a audiência para três meses depois. Estive lá no dia 14 de novembro de 2007, e a audiência foi marcada para o dia 10 de janeiro de 2008.

Tudo o que segue, neste caso, é bastante ilustrativo daquilo em que os Juizados Especiais têm se transformado. Após esperar três meses pela primeira audiência, D. pôde finalmente expor o seu caso diante do conciliador, uma bacharel em direito na oportunidade, aluna da Escola da Magistratura do Estado do Rio de Janeiro. D. compareceu à audiência sem a presença de um advogado, conforme havia sido aconselhada a fazer pelo escritório da Faculdade de Direito Candido Mendes, e, sem acordo na primeira audiência de conciliação, foi orientada a solicitar advogado na defensoria pública, o que fez prontamente no cartório do próprio juizado. A funcionária do cartório que a atendeu, ao se inteirar sobre o problema de D., disse-lhe que havia a possibilidade de que aquela causa não prosperasse no Juizado Especial Cível (JEC), em face de a ação demandar perícia técnica. Na audiência de julgamento, que, segundo D., foi monopolizada pela defesa e pelo advogado do condomínio, uma grande surpresa: o advogado do condomínio apresentava-se como um profissional experiente na atuação em Juizados Especiais, o que é no mínimo uma anomalia para uma justiça que foi pensada para evitar a necessidade desses profissionais. A sua expertise, no entanto, foi demonstrada em seguida ao seu breve discurso no juizado sobre o descuido de D. ao comprar um imóvel "ferrado" (expressão relatada por D.); segundo o relato dela, o advogado do condomínio disse que aquele JEC não poderia julgar tal causa por ela demandar perícia técnica, e isso a caracterizaria como uma causa "complexa”.

A defensora [pública] argumentou que já existia registro em ata de reclamação de outros moradores com respeito aos toldos. Alegou, também, que havia uma firma responsável pela instalação dos toldos e aqueles estavam ainda na garantia.

Para a indignação de D., a despeito, ainda, de ela ter apresentado laudos da prefeitura e da defesa civil os quais condenavam a fachada do edifício, a "juíza” (conciliadora), endossando a apreciação da técnica jurídica do advogado do condomínio e quase que repetindo as palavras dele, disse que o caso deveria ir para a justiça comum, por demandar perícia técnica, o que caracterizaria aquela causa como complexa.

A avaliação de D. dessa sua experiência nos Juizados Especiais mistura a natural frustração por não ter tido o seu caso apreciado por aquele juizado, após uma espera de oito meses entre a audiência de conciliação e a de julgamento, com um 
sentimento de que faltaram apenas bom senso e experiência para resolver a questão. Em suas palavras:

Tem que dividir por etapas. O tempo foi absurdo, muito sacrificante, o atendimento dos universitários foi excelente. O juiz [conciliadora] apesar de eu me sentir mais à vontade que num tribunal, mas eu tinha certeza que a juíza nunca tinha lido uma ata de reunião de condomínio. Acredito que sim, porque a juíza [conciliadora] demonstrou que não sabia que [morador] não pode fazer obra externa. A juíza não tinha experiência. Conta muito a experiência [...], meu irmão, por exemplo, tem experiência como membro de associação, como engenheiro da Caixa [Econômica Federal], entende mais direito e convenção [de condomínio] que um advogado.

Perguntada sobre como aquela experiência e, particularmente, a decisão do Juizado Especial tinham afetado a sua vida e sobre a avaliação que ela fazia da justiça, D. revela o caráter mais negativo desse tipo de engessamento normativo e formalista dos Juizados Especiais, provocado pela ação corporativista na luta pelo seu controle político-institucional. Nas palavras de D.:

Uma pessoa que está mal intencionada não faz o que eu fiz: perícia, procurar a justiça $[\ldots]$, meus familiares queriam que eu pedisse indenização, danos morais etc., eu só queria o conserto da parede. Agora não! Eu quero tudo! Eu estou mal intencionada e vou jogar com tudo: documentos, laudos. Depois que a gente passa dos quarenta a gente consegue perceber muitas coisas. Já a juíza não viu! O advogado do condomínio ainda brincou comigo dizendo que eu estava perdida, sem advogado.

Ou seja, além de não ter o seu problema resolvido em razão do preciosismo técnico do julgamento, D. acabou estimulada pelo Juizado Especial a encetar nova ação, retroalimentando e legitimando o moroso e custoso judiciário estatal.

\section{CONCLUSÕES}

Como vimos, o conjunto dos dados estatísticos e a análise das entrevistas confirmam, primeiramente, que a população passou a confiar e a conferir legitimidade às decisões pactuadas no âmbito dos Juizados Especiais. Em termos práticos, podemos afirmar que o aumento do número de litígios levados aos Juizados Especiais guarda relação direta com o progressivo aumento da confiança das partes envolvidas nas soluções judiciais obtidas nessa instância da justiça especial. 
No entanto, nas mesmas entrevistas, registramos algumas reclamações que evidenciam um progressivo esgotamento do sistema dos Juizados Especiais, dando-se o mesmo fenômeno experimentado pela justiça comum, qual seja, o aumento exponencial dos litígios para apreciação e eventual julgamento. Reclamações sobre a morosidade dos Juizados Especiais, por exemplo, começam a surgir com uma frequência acentuada nas opiniões emitidas pelos seus usuários, o que é preocupante para uma justiça que se propõe a ser descomplicada e desburocratizada, ou, em uma palavra: rápida. Assim, a burocratização e a morosidade permitem o questionamento da legitimidade (e mesmo da eficiência) do judiciário para a resolução dos conflitos.

O mais grave é a ausência de um debate maior sobre as causas do acúmulo de processos, pois a política judiciária vem se pautando pela eficiência na eliminação dos feitos judiciais. Estatisticamente, como vimos, muitas das demandas provêm de litigantes habituais, os quais deveriam ser fiscalizados e sancionados extrajudicialmente por órgãos estatais administrativos (agências reguladoras, Banco Central etc.), ou outros meios alternativos de resolução de conflitos.

Se essa omissão não é estimulada diretamente pelo próprio judiciário, ela lhe é, no mínimo, funcional, tendo em vista o receio dele de perder poder de ingerência sobre tantos litígios. Afinal de contas, a alegação de sobrecarga de trabalho dos tribunais e a consequente morosidade da prestação dos serviços jurisdicionais, ao mesmo tempo que serve de justificativa para a ineficiência e iniquidade da justiça, sempre teve destaque no discurso dos defensores de maiores recursos econômicos para o judiciário estatal.

Não restam dúvidas, portanto, de que os Juizados Especiais vieram para atender a uma demanda represada de litígios de menor impacto ofensivo e os quais não tinham soluções jurídicas perfeitas nas instituições tradicionais do judiciário, ou se solucionavam pelas vias tradicionais alheias ao judiciário. A gratuidade e a descomplicação burocrática dos rituais e procedimentos jurídicos dos Juizados Especiais são apontadas pela imensa maioria dos seus usuários como fatores motivadores do recurso a esse expediente judiciário. Em um país de imensas carências como o nosso, a falta de infraestrutura, recursos materiais e pessoal qualificado não demoraria mesmo a cobrar o seu preço. Na verdade, o enorme afluxo de litigantes aos Juizados Especiais e as consequentes perturbações no sistema daí decorrentes, tais como a demora das audiências e o congestionamento dos julgamentos, podem ser considerados externalidades positivas de todo o processo, pois que derivadas do aumento da legitimidade e da credibilidade dos serviços prestados pelos Juizados Especiais, além das boas qualidades da desburocratização e gratuidade do processo.

A expressão negativa desses problemas estaria principalmente na ameaça ao patrimônio de confiança e à agilidade da justiça especial. Tal judicialização de demandas rotineiras acaba por descaracterizar o Juizado Especial, que deixa de atuar como um tribunal de vizinhança para servir como balcão de atendimento a litígios de massa, em 
crescimento exponencial. Com isso, para atenderem à exigência de produtividade desse serviço público estatal, os juizados acabam burocratizando a sua função.

Assim, a nossa perspectiva para a análise dos problemas de morosidade e congestionamento dos Juizados Especiais aponta para a hipótese de que a pressão conservadora e corporativista dos operadores do direito, advogados, promotores e, especialmente, magistrados, tem atuado no sentido de promover a "reformalização" e "re-estatização" dos Juizados Especiais.

Não se trata, aqui, apenas de ressalvar o dado óbvio de que a restrição legal à seleção de conciliadores que forçosamente sejam, segundo a atual legislação estadual, juízes aprendizes da Escola de Magistratura diminuiu consideravelmente o escopo de profissionais e cidadãos de maneira geral habilitados a oferecer seus préstimos como árbitros legítimos de conflitos de baixo poder ofensivo social e aos indivíduos. Também nisso a alteração legal passou a atuar no sentido inverso ao espírito da Lei $n^{\circ}$ 9.099/95. Talvez, o prejuízo maior nesse tipo de legislação formalista e restritiva seja, na realidade, impossibilitar que decisões novas aflorem nos fóruns dos Juizados Especiais, baseadas em valores e em um senso de justiça mais próximos dos cidadãos comuns, bem como arranjos institucionais alternativos à justiça estatal.

A busca por conciliadores juristas e juízes leigos estudantes da Escola da Magistratura se revela, assim, uma opção pela eficiência da técnica jurídica, em detrimento da representatividade social. De fato, soluções conciliatórias demandam um trabalho artesanal de articulação e composição o qual exige tempo e capricho, valores que se chocam com as expectativas de eficiência e justiça rápida. A crescente busca por produtividade e pelos certificados ISO (padrões de "qualidade" impostos pelo mercado) demanda uma padronização de processos, como se as causas levadas ao judiciário fossem facilmente massificadas e convertidas em estatísticas funcionais. ${ }^{8}$

Com isso, os conflitos de vizinhança, que deveriam ser um dos problemas fulcrais dos Juizados Especiais, ficam totalmente à margem do atual modelo. Por demandarem uma abordagem quase artesanal, já que o conflito jurídico muitas vezes é a ponta de um iceberg de vários outros problemas, a burocratização e a extrema impessoalidade no tratamento das partes acabam produzindo uma justiça de pior qualidade.

Em suma, a experiência acumulada pelos Juizados Especiais revela aspectos significativos da cultura jurídica brasileira e da sua forma peculiar de assimilar as demandas contemporâneas por acesso à justiça.

Se, por um lado, a bem-sucedida experiência dos Juizados Especiais pode ser avaliada pelo aumento expressivo da demanda por seus serviços jurisdicionais, atingindo, dessa maneira, um dos seus objetivos fundamentais, que é o de promover e ampliar o acesso à justiça pelos cidadãos, por outro lado, uma parte deste patrimônio de legitimidade tem sido solapada pelas tentativas de desvirtuamento da sua natureza civil e da sua representatividade político-social. 
Idealizados como meios legítimos de aproximar os conceitos de justiça comunitarista - locais e culturalmente circunscritos, portanto - aos princípios formais e universalizantes da justiça estatal, os Juizados Especiais acabaram capturados pelos interesses corporativos e de empoderamento institucional. Sem dúvida, este talvez seja o aspecto mais negativo da trajetória dos Juizados Especiais: o esvaziamento da concepção de um serviço jurisdicional cuja eficácia, eficiência e legitimidade seriam retiradas da sua natureza civil e societária.

Os casos analisados dos Juizados Especiais de Niterói demonstram claramente que o peso da justiça estatal, legalista e burocrática começa a se abater sobre tais juizados, a partir de uma legislação secundária, que drenou boa parte do capital cívico e social dessa experiência. A legislação fluminense, em especial, que restringe o exercício das funções de juízes leigos e conciliadores ao corpo de alunos da Escola de Magistratura, evidencia o ataque da corporação aos princípios da representatividade social dos juízes leigos conforme o espírito da constituição, quando previu a criação dos Juizados Especiais.

Os primeiros efeitos dessa mudança começam a se refletir nas reclamações dos usuários da justiça especial a respeito da demora do processo judicial, as quais em muito lembram as reclamações comuns sobre a lentidão da justiça comum. As razões para isso muito possivelmente derivam das mesmas causas: apuro técnico, alegação de falta de expertise dos leigos para propalar sentenças e a habitual carência de infraestrutura estatal de suporte à processualística dos tribunais.

O pior a ocorrer será a extensão dos demais problemas da justiça comum aos juizados especiais, quais sejam, aqueles que obstam o acesso dos cidadãos mais pobres à apreciação arbitral, o que mataria definitivamente os objetivos centrais para os quais os juizados especiais foram criados.

: ARTIGO APROVADO (18/06/2010) : RECEBIDO EM 16/10/2009

NOTAS

1 Tanto no Gráfico 2 quanto no Gráfico 3, o número de feitos dos Juizados Especiais Cíveis de Niterói nos anos de 2006 e 2007 reflete uma diminuição provocada pela inauguração dos Juizados Especiais da Região Oceânica, área que se tornou densamente povoada nos últimos 15 anos.

2 Vamos desconsiderar aqui a experiência dos Juizados de Paz no Brasil imperial, entre 1829 e 1841, para focar exclusivamente na experiência recente dos Juizados Especiais, embora aquela experiência seja ilustrativa das primeiras ações do processo histórico brasileiro de centralização do poder judiciário pelas corporações de magistrados. 
3 Ressalte-se, ainda, que, devido ao sistema federado dos EUA, as small claims courts de cada estado norteamericano têm um funcionamento diverso, sendo que em cada localidade as reformas tiveram alcances diferentes. A experiência reformadora de Nova York, no entanto, assumiu um papel de referência para todo o país. Provocada pela "manifesta insatisfação da sociedade" com relação ao fato de que as Small Claims Courts atendiam mais às "empresas e grandes corporações do que às demandas dos pequenos negociantes e do cidadão comum", essa reforma determinou "a proibição da iniciativa de litígios por parte de pessoas jurídicas, a informalidade do processo, a ênfase na mediação e no arbitramento" (VIANNA et al., 1999, p. 160).

4 Várias são as alternativas ao juiz formalmente investido por concurso público. A Constituição Federal de 1988 prevê, em seu art. 98, o uso de juízes leigos em juizados especiais (inc. I) e juízes de paz, eleitos para o exercício de atividades conciliatórias e administrativas (inc. II).

5 Tal conceito é duramente criticado por Miguel Baldez, que entende inconstitucional tal previsão, por frustrar o ideal de acesso à Justiça objetivado pela nova ordem democrática: "A Constituição brasileira [...] apontou o caminho institucional quando previu em seu art. 98 os Juizados Especiais, neles consentindo a inclusão de juízes leigos e, com isso, abrindo caminho para o rompimento do monopólio do Poder Judiciário pela magistratura. Sem essa abertura não há como pensar, com conseqüências concretas, na democratização da justiça, aqui compreendida, além dos limites restritos e condicionantes do juridicismo, como fato existencial e, por isso, imbricada nas contradições econômicas, sociais, políticas e culturais. [...] Com o rompimento do monopólio (art. 98 da Constituição Federal), criavam-se as condições de abertura necessárias ao arejamento da ideologia jurídica burguesa, outras realidades enfim estariam representadas no campo jurídico-judiciário, outras culturas partilhariam com os juízes togados a compreensão dos fatos, iniciando-se um processo compartilhado de produção da Justiça. A utopia democrática, porém, teve pouco tempo de vida, pois veio a Lei n ${ }^{\circ} 9009$, de 26.6.1995, de implantação e regulação dos Juizados Especiais, e os juízes leigos da norma constitucional foram apropriados pela ideologia jurídica. E como se fez isso? Com aparente desconsideração pela classe dos advogados, leigos passaram a ser, em matéria cível, pelo menos, os advogados com mais de cinco anos de formados. Há na lei uma clara inconstitucionalidade, por não ter como conformar o conceito de leigo com o dispositivo legal”.

6 Em 2008, na lista das dez empresas mais reclamadas nos Juizados Especiais Cíveis de todo o estado do Rio de Janeiro, persistiam, com algumas alterações nas posições, as mesmas empresas e serviços líderes de reclamações nos Juizados Especiais Cíveis de Niterói: $1^{\circ}$ ) Unicard-Unibanco, com 53.949 ações, correspondentes a 15,26\% do total de ações; $2^{\circ}$ ) Oi Telefonia Fixa, com 31.476 ações, ou 8,9\% do total; $3^{\circ}$ ) Light, 23.879 ações, ou 6,76\% do total; 4) Vivo, com 17.846, ou 5,06\% do total; $5^{\circ}$ ) Ampla, com 16.778 ações, ou 4,75\% do total; $6^{\circ}$ ) Unibanco, com 15.851 ações, ou $4,48 \%$ do total; $7^{\circ}$ ) Banco Itaú, com 13.051 ações, ou 3,69\% das ações; $8^{\circ}$ ) Claro, com 11.688 ações, ou 3,31\% das ações; $9^{\circ}$ ) Oi Celular, com 10.162 ações, ou 2,87\% do total; 10) Tim Celular, com 9.127 ações, ou 2,58\% do total. Total de ações para o período considerado: 448.546. Fonte: Tribunal de Justiça do Rio de Janeiro; disponível em: $<$ http://www.tj.rj.gov.br>.

7 Por outro lado, tal judicialização dos conflitos envolvendo as concessionárias de serviços públicos reflete mais a inoperância do atual modelo regulatório e administrativo do que a ampliação de acesso à Justiça. Na verdade, essas empresas presentes na lista dos juizados especiais fluminenses também são frequentes nas estatísticas das agências reguladoras.

8 Merece destaque o fato de que, apesar de a Lei no 9.099/95 admitir conciliadores não juristas, e antes da lei estadual que restringiu o desempenho do cargo de conciliador aos estudantes da Escola da Magistratura, em Niterói todos eram bacharéis de direito ou estavam concluindo a faculdade de direito. Segundo o depoimento de uma conciliadora que trabalha no Juizado Especial Cível há aproximadamente oito meses, os casos mais bem sucedidos no sentido de chegar a um acordo entre as partes "são de pessoas físicas contra pessoas físicas. Contra empresas é mais difícil porque a empresa já vem com um posicionamento e às vezes não oferece acordo. Às vezes só na audiência com o juiz que oferecem uma proposta de acordo".

\section{REFERÊNCIAS BIBLIOGRÁFICAS}

BOBBIO, Norberto. Era dos direitos. Rio de Janeiro: Campus, 2002.

BOURDIEU, Pierre. O poder simbólico. Rio de Janeiro: Difel-Bertrand Brasil, 1989. 
CAPPELleTti, Mauro; GARTH, Bryan. Acesso à Justiça. Porto Alegre: SAFE, 1988.

. Controle judicial das leis no direito comparado. 2. ed. Porto Alegre: SAFE, 1992.

. Juízes legisladores? Porto Alegre: SAFE, 1999.

. Proceso, ideologias, sociedad. Buenos Aires: Ediciones Jurídicas Europa-America, 1974.

CARVAlHO, José Murilo. Cidadania no Brasil - O longo caminho. Rio de Janeiro, Civilização Brasileira, 2001.

DWORKIN, Ronald. Los derechos en serio. Barcelona: Ariel, 1984.

FAISTING, André Luiz. O dilema da dupla institucionalização do poder judiciário: o caso do juizado especial de pequenas causas. In: SADEK, Maria Tereza. O sistema de justiça. Sumaré: Idesp; Fundação Ford, 1999.

FRIEDMAN, Lawrence. Legal Culture and The Welfare State. In: TEUBNER, Gunther. Dilemmas of Law in the Welfare State. Berlim; Nova York: Walter e Gruyter, 1998.

The Legal System: A Social Perspective. Nova York: Russel Sage Foundation, 1975.

GARAPON, Antoine. O juiz e a democracia: o guardião das promessas. Rio de Janeiro: Renavan, 1999.

HABERMAS, Jürgen. Direito e democracia: entre facticidade e validade. v. 2. Rio de Janeiro: Tempo Brasileiro, 1997.

HESPANHA, Antônio Manuel. Cultura jurídica européia: síntese de um milênio. Florianópolis: Fundação Boiteux, 2005.

HARRINGTON, Christine B. Shadow Justice: the ideology and institutionalization of alternatives to court.

Contributions in Political Science, Westport, n. 133, 1985.

JUNQUEIRA, Eliane Botelho; VIEIRA, José Ribas; FONSECA, Maria Guadalupe Piragibe da. Juízes: retrato em preto e branco. Rio de Janeiro: Letra Capital. 1997.

LUHMANN, Niklas. Social Systems. Stanford: Stanford University Press, 1995.

. The Self-reproduction of Law and its Limits. In: TEUBNER, Gunther. Dilemmas of Law in the Welfare State.

Berlim; Nova York: Walter e Gruyter, 1998.

NELKEN, Davis; FEEST, Johannes. Adapting Legal Cultures. Oñati: IISL, 2001.

NEVES, Marcelo. A constitucionalização simbólica. Guarulhos: Editora Acadêmica, 1994.

PINHEIRO, Armando Castelar (Org.). Judiciário e economia no Brasil. São Paulo: Sumaré, 2000.

. A reforma do Judiciário: uma análise econômica. In: SEMINÁRIO INTERNACIONAL - SOCIEDADE

E REFORMA DO ESTADO, 1998, São Paulo. Disponível em:

<http://www.planejamento.gov.br/arquivos_down/seges/publicacoes/reforma/seminario/PINHEIRO.PDF>.

SANTOS, Wanderley Guilherme dos. Cidadania e justiça: a política social na ordem brasileira. Rio de Janeiro:

Campus, 1979.

SILVA, Ovídio A. Baptista. Processo e ideologia. Rio de Janeiro: Forense, 2004.

TEUBNER, Günther. Droit et reflexivité: I'auto-reference em droit et dans l'organization. Bruylant: LGDJ, 1996. . Dilemmas of Law in the Welfare State. Berlim; Nova York: Walter e Gruyter, 1988.

TROCKER, Nicolò. Processo civile e costituzione. Milão: Giuffrè, 1974.

VIANA LOPES, Júlio Aurélio. Democracia e cidadania: o novo Ministério Público brasileiro. Rio de Janeiro:

Lumen Juris, 2000.

VIANNA, Luiz Werneck (Org.) A democracia e os três poderes no Brasil. Belo Horizonte: Editora UFMG, 2002. . Perfil do magistrado brasileiro. Rio de Janeiro: Iuperj; AMB, 1996.

. Corpo e alma da magistratura brasileira. Rio de Janeiro, Revan, 1997.

VIANNA, Luiz Werneck et al..A judicialização da política e das relações sociais no Brasil. Rio de Janeiro: Revan, 1999. VALLINDER, Torbijörn. When the Curts go marching. In: TATE, C. Neal; VALLINDER, T. The Global expansion of judicial power. Nova York; Londres: New York City University Press, 1995.

WEBER, Max. Economia y sociedad. 2. ed. Cidade do México: Fondo de Cultura Económica, 1999.

YNGVESSON, Bárbara; HENNESSEY, Patrícia. Small claims, complex disputes: a

review of the small claims literature. Law and Society Review, Denver, v. 9, n. 2, 1975, p. 219-74.

ZAFFARONI, Eugênio Raul. Poder judiciário: crise, acertos e desacertos. São Paulo: Revista dos Tribunais, 1995.

\section{Marcelo Pereira de Mello}

Rua Barão de Guaratiba, 139 Glória - 22211-150

Rio de Janeiro - RJ - Brasil

mpmellolaunisys.com.br
PROFESSOR-ASSOCIADO DE SOCIOLOGIA DA UNIVERSIDADE Federal Fluminense (UFF)

Subcoordenador do Programa de Pós-Graduactão em SOCIOLOGIA E DIREITO (PPGSD) 
Delton R. Soares Meirelles

Rua Gavião Peixoto, 24 Icaraí - 24230-100 Niterói - RJ - Brasil deltonmeirelles@ig.com.br
PROFESSOR-ASSISTENTE DE DIREITO PROCESSUAL DA FACULdAdE de Direito da Universidade Federal Fluminense (UFF) 